\title{
Effects of Using Dynamic Geometry Activities on Eighth Grade Students' Achievement Levels and Estimation Performances in Triangles
}

\author{
Bilal Özçakı* \\ Elementary Mathematics Education, Ahi Evran University, Kirsehir, Turkey \\ Cahit Aytekin \\ Elementary Mathematics Education, Ahi Evran University, Kirsehir, Turkey \\ Bülent Altunkaya \\ Elementary Mathematics Education, Ahi Evran University, Kirsehir, Turkey
}

Bekir Kürşat Doruk

Computer Education and Instructional Technology, Abant İzet Baysal University, Bolu, Turkey

\begin{tabular}{|c|c|}
\hline & \multirow{6}{*}{$\begin{array}{l}\text { In this study, we administrated dynamic geometry activities which } \\
\text { provide students opportunities to explore and estimate geometric figures } \\
\text { to connect measurement estimation with geometry. The aim of the study } \\
\text { is to investigate effects of using dynamic geometry activities on eighth } \\
\text { graders' achievement levels and estimation performances in triangles. } \\
\text { The study was designed a quantitative research design. A pretest - } \\
\text { posttest experimental study was employed to investigate using dynamic } \\
\text { geometry activities on eighth grade students' achievement level and } \\
\text { estimation performance in triangles. Participants were } 63 \text { eighth graders. } \\
\text { The participants' ages vary between } 13 \text { and } 14 \text { years. Since the school is a } \\
\text { public school, it contains students at nearly every socio-economic level. } \\
\text { Experimental group consists of } 32 \text { students and comparison group } \\
\text { consists of } 31 \text { students. Dynamic geometry supported instruction and } \\
\text { traditional instruction methods were used in experimental and comparison } \\
\text { groups, respectively. The results revealed that teaching triangles with } \\
\text { instruction supported by dynamic geometry activities increased eighth } \\
\text { graders' performance in triangles. In addition, the instruction supported } \\
\text { by dynamic geometry activities had significant effects on eighth graders' } \\
\text { estimation performances in triangles. Using dynamic geometry activities } \\
\text { provides students experiences about conceptual bases of the relations in } \\
\text { triangles. Therefore, students who take a dynamic geometry instruction } \\
\text { make better estimations than those who did not take. }\end{array}$} \\
\hline $\begin{array}{l}\text { Received: } \\
27.08 .2015\end{array}$ & \\
\hline & \\
\hline & \\
\hline & \\
\hline & \\
\hline
\end{tabular}

*Correspondence: bilalozcakir@gmail.com 


\section{Introduction}

Geometry and measurement are important components of school mathematics. They develop students' mathematical reasoning abilities, spatial intuition about real world, and knowledge for higher level mathematics. In addition, estimation is an important mathematical skill closely linked to number sense and measurement (Lucas \& Son, 2013).

Learning how to estimate measurement is important. It is an essential skill in daily life. In addition, measurement estimation provides a useful skill in order to make a good decision about exact measurement in real life. For example, Siegler and Booth (2004) stated some situations in which estimation is a crucial. These are making a decision about how much time will it take to get home, how heavy is an object, and how far is the distance between here and there. As it can be understood clearly, life would be difficult without the ability to estimate reasonably accurate (Siegler \& Booth, 2004).

To our knowledge, studies conducted are consisting of using either visualization of physical objects on paper-pencil environment or physical manipulative (Segovia \& Castro, 2009; Siegler \& Booth, 2005; Workman \& Ahn, 2011). There have been few studies or no studies about using dynamic manipulations for teaching estimation of measurements. Throughout of this paper, estimation term is used for measurement estimation.

\section{Theoretical Perspective}

Visualization of mathematical abstractions supports students to develop a strong sense of measurement. Using concrete materials in lessons is thought to better enable students to comprehend mathematical concepts (Gilliland, 2002). Similarly, technological tools can provide such visualizations on computer screen with adding feature of dynamic manipulations. With these features, students are able to see other views of the same object, and observe the change of this object by interacting with different situations of it.

Pea (1987) defined technological tools for education as cognitive tools (CT). CT helps to go beyond of limitations of human mind (Pea, 1987). In addition, CT can facilitate mathematics learning (Zbiek, Heid \& Blume, 2007). CT can provide external representations of a mathematical object. With the help of CT, we can show or use multiple representations of mathematical objects in instructional phase. For example, GeoGebra, which is dynamic geometry software, can create hot-links for mathematical objects to show their both symbolic representations and visual representations at the same time (Hohenwarter \& Jones, 2007). Hot-links provide to see changes in an object with multiple representations of it at the same time.

With the help of the technology we can design both technical and conceptual learning activities. Similarly, CT can be used for procedural works, gaining intuition, discovering new patterns, exploring, proving and testing (Zbiek, Heid \& Blume, 2007). This construct of the $\mathrm{CT}$ is suitable for teaching geometry. Especially, in middle school level, students generally need spatial figures or diagrams to construct knowledge about geometrical concepts (Laborde, Kynigos \& Strasser, 2006).

\section{Students' Performance in Geometry and Cognitive Tools}

As a result of the teaching methods, which lack of opportunities for student to construct his or her own knowledge, students may memorize a definition, which they may repeat when they are asked for it (Battista, 2007; Clements \& Battista, 1992). These 
misconceptions are likely to be a result of that; students do not have enough opportunities to see different views of a same figure in paper - pencil environment. In CT, students have the opportunity to see and explore different constructions and views of an object.

One of the cognitive tools' categories for geometry education is dynamic geometry software (DGS). In DGS objects drawn or constructed can be moved and resized interactively in contrast to traditional paper - pencil environment (Dye, 2001). Students can manipulate the geometric objects and can observe changes in multiple representations of the objects provided by hot-links and with real-time measures (Battista, 2002; Laborde, Kynigos, \& Strasser, 2006). Therefore, they can test, observe, record, manipulate and predict geometric objects, concepts, beliefs and theorems with DGS (Forsythe, 2007; Hill \& Hannafin, 2001). GeoGebra is used as a CT in the current study. GeoGebra is an interactive geometry tool for school mathematics (Hohenwarter, Hohenwarter \& Lavicza, 2010).

DGS can give easier access to lots of geometrical concepts and different views of geometrical constructs than paper and pencil construction. Because students can change or move the shape that they draw and they can see different aspects of it.

\section{Students' Estimation Performance and Geometry}

Middle school students use estimation skills to approximate measurement and computation. However, learning estimation and connecting it with geometry are difficult for students (Lucas \& Son, 2013).

In the literature, there are some studies which have focused on useful role of the estimating strategies in measurement (McLaugin, 1981; Piaget \& Szmanska, 1964; Segovia, 1997) while other ones have focused on developing estimation skills in measurement (Bright, 1979; Markovits \& Hershkowits, 1993; McLaughin, 1981; Pajera, 2001), also the role of mental images in facilitating students' estimation skills in measurement (Siegel, Goldsmiths \& Madson, 1982). In literature review, it is seen that there is few studies using dynamic geometry activates to develop estimating skills in geometry.

In real life situations, we rarely used exact calculations. Most of the time estimating a value or a measure is enough for us. In this sense, teaching students to estimate in mathematics can be considered as a bridge on the gap between real life and school mathematics (Korenova, 2014). When the accurate measurement is not necessary, we decide in many situations by using our estimation ability (Adams \& Harrel, 2010). Many researchers define estimation as a process of producing answers without performing exact computations while these answers close enough for making decisions (Reys, Lindquist, Lambdin \& Smith, 2009). Van de Walle, Karp, and Bay-Williams (2010) stated that estimating a measurement is a process in which one makes measurements without using any measurement tools and by using mental and visual information. In addition, Olkun and Toluk-Uçar (2006) claimed that students' estimation performance reflects students' conceptual knowledge level in the estimated subjects.

Estimation in geometry can be thought as a part of measurement estimation. Because some studies about estimation ability focused on geometrical concepts like area, volume and length (Brigth, 1979; Forrester, 1990; Segovia \& Castro, 2009; Siegel et al. 1982). Dynamic geometry software allows students to see the changes of the shapes dynamically. In this study, one of our interests is to investigate the effects of dynamic geometry activities on students' estimation performance in triangles. 
Considering the developments in the educational policies (Ministry of National Education [MoNE], 2009, 2013) and the opportunities of using cognitive tools in learning environment, this study provides dynamic activities to enhance students' learning of the domain of triangles. Therefore, the aim of the study is to investigate effect of using dynamic geometry activities on eighth grade students' achievement level and estimation performance in triangles.

The study focused on following research questions;

- What are the effects of instruction based on dynamic geometry activities compared to traditional instruction method on eighth grade students' achievement in triangles?

- What are the effects of instruction based on dynamic geometry activities compared to traditional instruction method on eighth grade students' estimation' scores?

\section{Methodology}

In this current study, a quantitative research design was used to analyze the situation. A pretest-posttest experimental study was employed to investigate using dynamic geometry activities on eighth grade students' achievement level and estimation performance in triangles.

\section{Participants}

Sixty-three children at eighth grade from a public middle school in Kırşehir - Turkey participated in this study. The participants' ages vary between 13 and 14 years. The school is a public school; therefore, it contains students at nearly every socio-economic level.

The experimental group which was received dynamic geometry supported instruction consisted of 32 children. The comparison group which received traditional instruction consisted of 31 children. These groups were randomly selected from five eighth grade classes from one public middle school in Kırşehir - Turkey. In addition, the same teacher teaches mathematics course both of these classes.

\section{Materials and Procedure}

This study took place at a middle school in Kırşehir - Turkey and it was designed for 8th grade students for the domain of triangles. In Elementary School Mathematics Curriculum (ESMC), there are seven objectives for the domain of triangles (MoNE, 2009). These are;

(1) Students link sum or difference of lengths of two sides of triangle with length of third side.

(2) Students link sides' lengths of a triangle with angles at opposite of each one.

(3) Students draw a triangle from given measures of enough number of elements.

(4) Students construct median, angle bisector and altitude of a triangle.

(5) Students explain the congruence terms associated with triangles.

(6) Students explain the similarity terms associated with triangles.

(7) Students form the statement of the Pythagorean Theorem and solve related problems.

In comparison group, the researchers' role was observer. Teacher was implemented the concept by relying on the course textbook which was written by Canpekel, M. (2009). In this group, treatment was generally based on teacher instruction and in some cases (i.e. "The relationship between sides' lengths of triangles and interior angles") short-time student-based 
activities were administrated for group works.

On the other hand, in experimental group, eleven dynamic geometry activities were administrated in learning processes. The big ideas of the activities are to develop conceptual knowledge of students in the domain of triangles by observing, exploring, constructing triangles, and to be able to make transitions between computer environment and paper pencil environment by using students' work sheets. During the tasks, no feedback was given to students by teacher until the task has been accomplished by the most of the students.

Since the third and fourth objectives require drawing and constructing, the activities about these objectives include actions of drawing and constructing triangle and its elements. On the other hand, in the other activities, students were supposed to manipulate given figure and to observe changes in measures. In the meantime, they took notes about changes, and they were asked to examine what cause these changes.

As an example for the activities in the study first two activities were described in detail. The first two activities address to first objective which is about to link sum or difference of lengths of two sides of triangle with length of third side. In these activities, some hints are given to make GeoGebra usage easy for students, to eliminate the difficulties which may result from the usage of GeoGebra, and to focus on mathematical objectives. In the first activity, a triangle $\mathrm{ABC}$ with $|\mathrm{AB}|=6 \mathrm{~cm}$ and $|\mathrm{AC}|=8 \mathrm{~cm}$ is given (Figure 1).

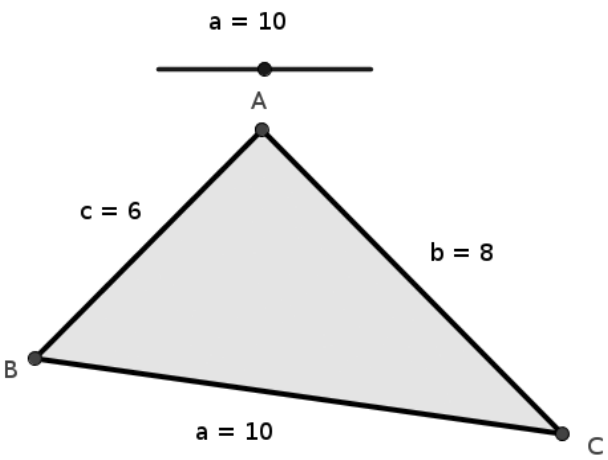

Figure 1. First activity: linking sum or difference of lengths of two sides of triangle with length of the other side

In this triangle, length of $|\mathrm{BC}|$ changes dependently a slider. Students are asked to change length of $|\mathrm{BC}|$ freely by using slider and note the $|\mathrm{BC}|$ and perimeter of the $\mathrm{ABC}$ triangle for ten different positions of slider. Afterward, they try to answer questions in worksheet according to their observations. In this activity, students are supposed to investigate the relationships between lengths of sides and triangular inequality. The purpose of the second activity is to assess students' learning about triangular inequality concept (Figure 2).

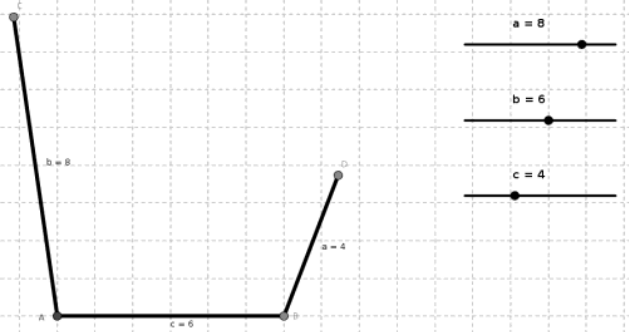

Figure 2. Second activity: triangular inequality concept 


\section{Instruments}

In this study, Triangles Achievement Test (TAT) and Estimation Test in Triangles (ETT) were used as data gathering tool. Both the TAT and ETT were developed by the researchers who are specialist in elementary mathematics education. In figure 3 and figure 4 , some sample questions of the TAT and ETT were given respectively. The real versions of the tests were developed in Turkish. The examples of items given here were translated from Turkish to English.

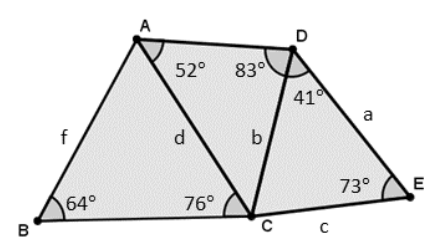

Which of the following inequalities is true for triangles $A B C, A C D$ and $D C E$ ?

$\begin{array}{lll}\text { A) } a>b>d>c>f & \text { B) } d>b>c>f>a\end{array}$

C) $f>d>b>a>c \quad$ D) $b>d>c>a>f$

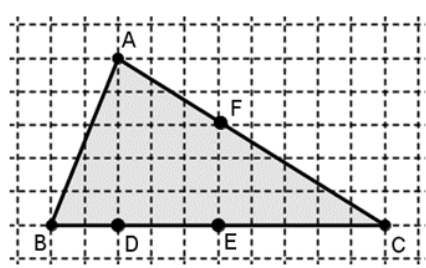

In $\mathrm{ABC}$ triangle, the perpendicular bisector of $|\mathrm{BC}|$ passes through on which points?
A) A and $E$
B) $A$ and $D$
C) F and D
D) $F$ and $E$

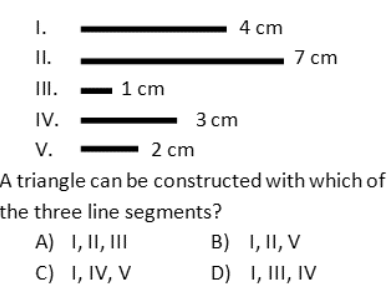

Figure 3. Sample questions of the TAT

Which of the following options, a triangle cannot be constructed with given line segments?

A)

B)

C)

D)

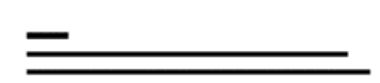

Which of the following options, a wide angled triangle can be constructed with given line segments?

B)

C)

D)

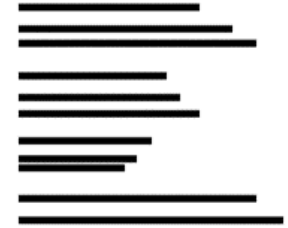

Which of the following options, the angles of the triangle are the closest $65^{\circ}, 60^{\circ}$ and $55^{\circ}$.

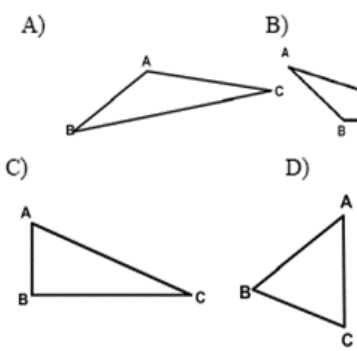

Figure 4. Sample questions of the ETT

A pilot study was conducted for instruments in order to determine difficulty of questions, and to check and verify their reliability, appropriateness, discrimination of items. In TAT there were 20 multiple-choice items and the ETT included 30 multiple-choice items. Both the TAT 
and ETT were developed by considering the seven objectives of ESMC which were explained in the previous section. The maximum point is 100 and the minimum point is 0 for both TAT and ETT. These tests were piloted before the study with 187 eighth graders from three public middle school in the city center of Kirşehir. Cronbach's alpha reliability coefficient of the ETT was found as 0.79 and of the TAT was found as 0.77 for the pilot study. In addition, in this study, Cronbach's alpha reliability coefficient of the ETT was found as 0.76 and of the TAT was found as 0.79 .

\section{Results}

Before analysing differences between groups in estimation and academic performances after the study, differences between groups in these performances were tested by considering pre-test results. There did not appeared to be significant differences between experimental $(\mathrm{M}=63.5, \mathrm{SD}=17.4)$ and comparison groups $(\mathrm{M}=61.3, \mathrm{SD}=20.2)$ in estimation performance; $\mathrm{p}=0.66$. In addition, academic performance in triangles differences between experimental $(M=54, S D=25.5)$ and comparison groups $(M=62, S D=24.4)$ were not significant; $p=0.22$, before the study. Therefore, there was not any difference between groups before the study. According to these results, it can be said that before the study the experimental and comparison group students are similar to each other about performances in estimation and academic achievement in triangles. Therefore, a multivariate analysis of variance (MANOVA) was conducted to analyze whether significant differences exist between students with and without support of dynamic geometry activities in instruction, since we have two dependent variables (estimation and academic performance) and one independent variable (method of instruction). Several tests were performed to fulfil assumptions made before the MANOVA test.

We conducted a One Way MANOVA on the students' performance scores. The analysis revealed that there was a significant main effect of group, which students attended, on their combined performances, $\mathrm{F}(2,57)=5.95, \mathrm{p}=0.004$; Wilks' Lambda $=0.83$; observed power $=0.86$; partial eta squared $=0.17$ which can also be represented as Cohen's $\mathrm{f}^{2}=0.21$ (Table 1). This effect size indicates medium effect size according to Cohen's "Set Correlation and Multivariate Methods' Effect Size" (Cohen's f': Small Effect Size = 0.02; Medium Effect Size $=0.15 ;$ Large Effect Size = 0.35 [Cohen, 1988; pp.477-478]).

Table 1. Multivariate Test Results

\begin{tabular}{ccccc}
\hline & Value & F & Sig. & $\begin{array}{c}\text { Partial Eta } \\
\text { Squared }\end{array}$ \\
\cline { 2 - 5 } Wilks' Lambda &, 83 & 5,95 &, 004 &, 17 \\
\hline
\end{tabular}

When the results for students' estimation and academic performances in triangles were considered separately, there were significant differences, using a Bonferroni adjusted alpha level of .025 , in both students' estimation performance scores $(F(1,58)=7.26, p=0.009$, partial eta squared $=0.111$ or Cohen's $\left.f^{2}=0.125\right)$ and academic performance scores $(F(1,58)$ $=7.124, \mathrm{p}=0.010$, partial eta squared $=0.109$ or Cohen's $\left.\mathrm{f}^{2}=0.122\right)($ Table 2$)$.

Table 2. MANOVA Results; Test of Between-Subjects Effects

\begin{tabular}{lrrrc}
\hline & Mean Square & $F$ & Sig. & $\begin{array}{c}\text { Partial Eta } \\
\text { Squared }\end{array}$ \\
\cline { 2 - 5 } Achievement & 2281,7 & 7,124 &, 010 &, 109 \\
Estimation & 2801,7 & 7,258 &, 009 &, 111 \\
\hline
\end{tabular}


The Cohen's $\mathrm{f}^{2}$ indicates that using dynamic geometry activities have small effect size on students' estimation performance, and have also small effects size on students' academic achievement.

Inspection of mean scores (Table 3) indicated that students in dynamic geometry supported instruction group achieved higher levels of performance in estimation $(M=65.83)$ than students in tradition instruction group $(M=52.17)$.

Table 3. Mean Scores of TAT and ETT

\begin{tabular}{|c|c|c|c|}
\hline \multicolumn{2}{|l|}{ Mean Scores } & Experimental Group & Comparison Group \\
\hline & Estimation & 65,83 & 52,17 \\
\hline & Achievement & 72,00 & 59,67 \\
\hline
\end{tabular}

In addition, it was revealed that students in dynamic geometry supported instruction group achieved slightly higher levels of academic performance $(\mathrm{M}=72)$ than students in tradition instruction group $(\mathrm{M}=59.67)$.

\section{Discussion}

This study examined effects of using dynamic geometry activities on eighth grade students' academic achievement and estimation performance in triangles. More specifically, the effect of GeoGebra based activities for triangles on students' performance in triangles was examined. In this study, we used the term of performance in estimation because we used a multiple choice test to determine students' estimation levels in triangles.

We rarely use exact calculation, and estimation often meets our needs (Korenova, 2014). In order to satisfy this need, estimation is taught through mathematics. Cognitive tools can be considered as a practical way to teach theoretical concepts of mathematics with situations close to real life (Daher \& Shahbari, 2013). In this study, we aimed to provide dynamic activities to enhance students' learning and estimation performances in the domain of triangles. The preliminary analysis shows that students' combined performances in estimation and academic achievement in triangles were significantly dependent on which group they had attended. In other words, instruction supported by dynamic geometry tasks has positive effect on students' performances in both estimation and academic achievement in triangles. This enhancement in performance corresponds with previous research in which it is stated that dynamic geometry software has a positive effect on students' learning and performance on mathematics (Baki, Kosa, \& Guven, 2011; Caglayan, 2014; Doğan \& İçel, 2011; Gecü, 2011; Güven \& Karataş, 2009; Hall \& Chamblee, 2013; Hohenwarter, Hohenwarter \& Lavicza, 2010; Idris, 2007; Jiang \& White, 2012).

With the following analysis of results, it is seen that students, who took advantage of dynamic geometry activities in learning process, have performed higher performances of estimation in triangles than other students. Since, dynamic geometry software provides to students immediate feedback for their progresses and choices, they can see and understand where they had been wrong and how can they proceed further by manipulating objects and doing mathematics with experiments. Students can work on tasks individually, or as in this study by group, at their own paces and can get real-time feedback for what they do with cognitive tools (Korenova, 2014). Therefore, this result is consistent with statements of Korenova (2014) and Samkova (2013) which can be summarized as the immediate feedback feature of dynamic geometry software can help to enhance students' performances in estimation and provide a 
way to make different estimation strategies.

Moreover, it is seen that students have achieved slightly higher level of academic performance in triangles with dynamic geometry supported instruction. This result is parallel with previous studies (Budi, 2011; Doğan \& İçel, 2011). The students in experimental group have the opportunity to verify the conditions with the chance of exploring and observing objects by using GeoGebra's tools. Therefore, these students have interactive ways to understand and see accuracy of their estimations and to observe construction conditions of geometric features for each object in tasks. Taking mathematics from theoretical to practical level with dynamic geometry software helped these students to understand and learn concepts with an interactive way. Students can get feedback for their works, information about their processes, and result of these progresses with visual representations. Therefore, making concrete and visualizing nearly all steps on given task and exploring different situations of objects by manipulating them in dynamic geometry tasks helped these students to understand the concepts by constructing geometrical objects and exploring mathematics concepts.

\section{Conclusion}

Measurement estimation is heavily depends on previous experience. As a result of this study, using dynamic geometry activities provides students such an experience about conceptual bases of the relations in triangles. Therefore students who take a dynamic geometry instruction make better estimations than those who did not take.

In this study, effects of dynamic geometry software on students' both estimation and academic performances were investigated. To our knowledge, it was the one of the first studies about integrating dynamic geometry with measurement estimation. Therefore, future studies should be conducted about effects of dynamic geometry software on estimation to understand in depth and ensure its effects for this area, and also with other software from GeoGebra. In addition, this study was conducted through the concept of triangle, so other concepts of middle school mathematics can be investigated for this purpose.

\section{Acknowledge}

This study has been funded by Ahi Evran University, PYO-EGF.4001.13.003.

\section{References}

Adams, T.L. \& Harrel, G. (2010). A Study of Estimation by Professionals at Work. Journal of Mathematics \& Culture, November, 5 (2).

Baki, A., Kosa, T., \& Guven, B. (2011). A Comparative Study of The Effects of Using Dynamic Geometry Software and Physical Manipulative on The Spatial Visualization Skills of Pre-Service Mathematics Teachers. British Journal of Educational Technology, 42(2), 291-310.

Battista, M. T. (2002). Learning geometry in a dynamic computer environment. Teaching Children Mathematics, 8(6), 333-339.

Battista, M. T. (2007). The development of Geometric and Spatial Thinking. In F. K. Lester, Jr., (Ed.), Second Handbook of Research on Mathematics Teaching and Learning. Charlotte, NC: Information Age Publishing.

Bright, G.W. (1979). Measuring experienced teachers' linear estimation skills at two levels of abstraction. School Science and Mathematics, 79, 161-64. 
Budi, M. (2011). Traditional Teaching About Angles Compared To An Active Learning Approach That Focuses On Students Skills In Seeing, Measuring And Reasoning, Including The Use Of Dynamic Geometry Software: Differences In Achievement. In PROCEEDINGS International Seminar and the Fourth National Conference on Mathematics Education. Department of Mathematics Education, Yogyakarta State University.

Caglayan, G. (2014). Static versus Dynamic Disposition: The Role of GeoGebra in Representing Polynomial-Relational Inequalities and Exponential-Logarithmic Functions. Computers in the School, 31:339-370.

Canpekel, M. (2009). Illköğretim 8. sınıf matematik ders kitabı. Ankara: Dikey Yayıncılık.

Clements, D. H. \& Battista, M. T. (1992). Geometry and spatial reasoning. In D.A Grouws, (ed.), Handbook of Research on Mathematics Teaching and Learning, pp .420-464. Macmillan, New York.

Daher, W. M., \& Shahbari, J. A. (2013). Pre-Service Teachers'modelling Processes Through Engagement with Model Eliciting Activities with A Technological Tool. International Journal of Science and Mathematics Education, 1-22.

Doğan, M. \& İçel, R. (2011). The Role of Dynamic Geometry Software in The Process of Learning: GeoGebra Example about Triangles. International Journal of Human Sciences, 8(1), ISSN: 1303-5134.

Dye, B. (2001). The Impact of Dynamic Geometry Software on Learning. Teaching Mathematics and Its Applications, 20(4).

Forrester, M. A. (1990). Exploring estimation in young children. Educational Psychology, $4(10)$.

Forsythe, S. (2007). Learning geometry through dynamic geometry software, Mathematics Teaching, 202, 31-35.

Gecü, Z. (2011). The effect of using photographs with dynamic geometry software on achievement and geometric thinking level. Unpublished master thesis, Marmara University, İstanbul, Turkey.

Gilliland, K. (2002). Why not just use a formula? Mathematics Teaching in the Middle School, 7, 510-511.

Güven, B. \& Karataş, İ. (2009). The Effect of Dynamic Geometry Software (CABRI) on PreService Elementary Mathematics Teachers' Academic Achievement About Locus Problems. Ankara University Journal of Faculty of Educational Sciences (JFES), 42(1), 1.

Hall, J., \& Chamblee, G. (2013). Teaching Algebra and Geometry with GeoGebra: Preparing Pre-Service Teachers for Middle Grades/Secondary Mathematics Classrooms. Computers in the Schools, 30:12-29.

Hershkowitz, R. (1989). Visualisation in geometry - two sides of the coin. Focus on Learning Problems in Mathematics, 11(1), 61-76. http://dx.doi.org/10.1017/CBO9781139013499.006

Hill, J. R. \& Hannafin, M. J. (2001). Teaching and Learning in Digital Environments: The Resurgence of Resource-based Learning. Educational Technology Research and Development, 49(3), 37-52.

Hohenwarter, J., Hohenwarter, M. \& Lavicza, Z. (2010). Evaluating Difficulty Levels of Dynamic Geometry Software Tools to Enhance Teachers' Professional Development. International Journal for Technology in Mathematics Education, 17(3), 127-134.

Hohenwarter, M. \& Jones, K. (2007). Ways of linking geometry and algebra: the case of Geogebra. Proceedings of the British Society for Research into Learning Mathematics, 27(3), 126-131. 
Idris, N. (2007). The effect of Geometers' Sketchpad on the performance in geometry of Malaysian students' achievement and van Hiele geometric thinking. Malaysian Journal of Mathematical Sciences, 1(2), 169-180.

İçel, R. (2011). Effects of computer based teaching on students' mathematics achievements: Example of GeoGebra. Unpublished master thesis, Selcuk University, Konya, Turkey.

Jiang, Z. \& White, A. (2012).An Efficacy Study on the Use of Dynamic Geometry Software. In the Proceedings of the 12th International Congress on Mathematical Education.

Koreňová, L (2014). The Role of Digital Materials in Developing the Estimation Ability in Elementary and Secondary School Mathematics. ACTA MATHEMATICA 17, 87.

Laborde, C., Kynigos, K. H. \& Strasser, R. (2006). Teaching and learning geometry with technology. In A. Gutiérrez \& P. Boero (Eds), Handbook of research on the psychology of mathematics education: Past, present and future (pp. 275-304). Rotterdam, The Netherlands: Sense Publishers.

Lucas, K. \& Son, J. (2013). Integrating Measurement and Computational Estimation in Geometry. Mathematics Teaching in the Middle School, Vol. 18, No. 5, 308-316

Markovits, Z. \& Herskovits, R. (1993). Visual estimation of discrete quantities. ZDM. 93/4, 137-140.

McLaughin, J. (1981). Development of children's ability to judge relative numerosity. Journal of Experimental Child Psychology, 31, 103-114.

Ministry of National Education, (2009). İlkögrretim Matematik Dersi (6 - 8. Sinıflar) Öğretim Programı. Retrieved June 12, 2012, from TTKB website:http://ttkb.meb.gov.tr/dosyalar/programlar/ilkogretim/matematik6_8.rar.

Ministry of National Education, (2013). Ortaokul Matematik Dersi (5 - 8. Sinıflar) Öğretim Programı. Talim Terbiye Kurulu Başkanlığı, Ankara.

Olkun, S. \& Toluk Uçar, Z. (2006) .İlköğretimde Matematik Öğretimine Çağdaş Yaklaşımlar [Contemporary Approaches in Elementary Mathematics Education], Ankara: Ekinoks Yayıncilik.

Pajera, J.L. (2001). Estimation de candidades discretas por alumnos de Magisteria (Memoria de Tercer Ciclo). Estimation of discrete quantities by preservice teachers (Third Cycle Report). Mathematics Didactics Department, University of Granada.

Pea, R. D. (1987). Cognitive Technologies for Mathematics Education. In A. H. Schoenfeld (Ed.), Cognitive Science and Mathematics Education (pp. 89-122). Hilldale, NJ: Erlbaum.

Piaget, J.L. \& Szeminska, A. (1964). Genesis del numero en el nino, Guedalupe, Buenos Aires.

Reys, R. E., Lindquist, M. M., Lambdin, D. V., \& Smith, N. L. (2009). Helping children learn mathematics (9th ed.). Danvars: John Wiley \& Sons.

Samková, L.(2013).Volume and area ratios with GeoGebra. North American GeoGebra Journal, 2(1), str. 10-13, 2013.

Segovia, I. (1997). Estimación de cantidades discretas. Estudio de variables y procesos. Granada: Comares.

Segovia, I., \& Castro, E. (2009). Computational and measurement estimation: curriculum foundations and research carried out at the University of Granada, Mathematics Didactics Department. Electronic Journal of Research in Educational Psychology, 17(7), 499-536.

Siegel, A. W., Goldsmith, L. T., \& Madson, C. R. (1982). Skill in estimation problems of extent and numerosit. Journal for Research in Mathematics Education, 3(13), 211232.

Siegler \& Booth (2004). Development of Numerical Estimation in Young Children. Child Development. 75(2), 428-444. 
Van de Walle, J. A., Karp, K. S., \& Bay-Williams, J. M. (2010). Elementary and middle school mathematics: Teaching developmentally. Boston, MA: Allyn \& Bacon.

Workman, J. E., \& Ahn, I. (2011). Linear measurement and linear measurement estimation skills in apparel design. Clothing and Textiles Research Journal, 0887302X11407911.

Zbiek, R. M., Heid, M. K. \&Blume, G. W., \& Dick, T. P. (2007).Research on technology in mathematics education: The perspective of constructs. In F. Lester (Ed.), Handbook of research on mathematics teaching and learning (Vol. 2, pp. 1169-1207). Charlotte, NC: Information Age Publishing. 